\title{
Lactate and ethanol dehydrogenase activities in continuous cultures of Clostridium thermosaccharolyticum LMG 6564
}

\author{
Marc Vancanneyt, Paul De Vos, ${ }^{*}$ Linda Vennens and Jozef De Ley \\ Laboratorium voor Microbiologie en microbiële Genetica, Rijksuniversiteit, K.L. Ledeganckstraat 35, B-9000 Gent, \\ Belgium
}

(Received 4 May 1990; accepted 13 June 1990)

\begin{abstract}
The pattern of ethanol and lactate formation by continuous cultures of Clostridium thermosaccharolyticum LMG 6564 under glucose limitation is affected by culture conditions such as pH and dilution rate. NADH- and NADPHmediated lactate dehydrogenase (LDH; EC 1.1.1.27) and alcohol (ethanol) dehydrogenase (ADH; EC 1.1.1.1 and EC 1.1.1.2) activities were measured in cell extracts from continuous cultures grown under different conditions. In conditions of high product formation, the NADH-mediated reaction was higher than the NADPHmediated reaction for both LDH and ADH. LDH showed an absolute requirement for fructose 1,6-bisphosphate (FBP). Both NADH- and NADPH-linked LDH reactions were cytoplasmic, not sensitive to oxygen, and had a pH optimum of 6.0-6.5; the temperature optimum was $55-60^{\circ} \mathrm{C}$. The reverse reaction (lactate oxidation) could not be demonstrated. ADH activity was found in the particulate fraction of the cell lysate and was sensitive (not completely, but irreversibly) to oxygen. The temperature and $\mathrm{pH}$ optima were $43{ }^{\circ} \mathrm{C}, \mathrm{pH} 7.0$ and $45^{\circ} \mathrm{C}, \mathrm{pH} 8.8$ for the NADH- and NADPH-mediated reactions, respectively. The production of at least two different ADHs is likely. LDH and ADH seemed to be regulated at the level of enzyme synthesis (direct correlation between the in vitro activities and the lactate and ethanol yields in the culture) with a second regulation of LDH by FBP at the reaction level.
\end{abstract}

\section{Introduction}

Several factors account for the biotechnological interest in enzymes from thermophiles (Zeikus, 1979). In the present work we report on the formation and regulation of alcohol dehydrogenase (ADH; EC 1.1.1.1 and EC 1.1.1.2) and lactate dehydrogenase (LDH; EC 1.1.1.27) in continuous cultures of Clostridium thermosaccharolyticum, a thermophilic saccharolytic bacterium. NADPH-linked ADH has been detected during the spore-forming phase of $C$. thermosaccharolyticum (Hsu \& Ordal, 1970). As far as we know, this is the only report on these enzyme activities for this bacterium. More data are available for other thermophiles. For example, cell extracts of Clostridium thermohydrosulfuricum display both NADH- and NADPH-linked ADH activities (Lamed \& Zeikus, 1981; Turunen et al., 1987) as well as NADH-linked LDH activity (Turunen $e t$ al.,

\footnotetext{
Abbreviations: ADH, alcohol dehydrogenase; FBP, fructose 1,6bisphosphate; LDH, lactate dehydrogenase.
}

1987). With another strain and under anaerobic assay conditions Hyun et al. (1985) discovered a NADPHlinked LDH. Clostridium thermocellum shows NADHmediated ADH and LDH activities (Lamed \& Zeikus, $1980 b$ ). Thermoanaerobium brockii contains NADH- and NADPH-linked ADH as well as NADH-linked LDH (Lamed \& Zeikus, 1980a). All the LDH activities mentioned so far are under allosteric control by fructose 1,6-bisphosphate (FBP), as reported by Wolin (1964) for Streptococcus bovis LDH.

Limited information is available about the impact of these enzymes on the fermentation pattern of the thermophilic clostridia. This in contrast to our knowledge of the fermentation metabolism of the mesophilic clostridia. Indeed, during the last two decades, research on the fermentation metabolism of Clostridium kluyveri (Hillmer \& Gottschalk, 1972, 1974; Lurz et al., 1979), Clostridium pasteurianum and/or Clostridium butyricum (e.g. Jungermann et al., 1973; Petitdemange et al., 1976; Mitchell et al., 1987), and certainly Clostridium acetobutylicum (see, for example, Jones \& Woods, 1986; Freier \& Gottschalk, 1987; Wiesenborn et al., 1989a, b; Clark 
et al., 1989; Rao \& Mutharasan, 1989), has been encouraged, because of the importance of some of these organisms for the production of solvents (ethanol, butanol and acetone) or fuels (hydrogen gas and ethanol).

Pyruvate is the branch-point intermediate in the fermentation of glucose in the above-mentioned clostridia, including the thermophiles. The enzymes competing for pyruvate are LDH and pyruvate :ferredoxin oxidoreductase. When pyruvate is metabolized to products other than lactic acid, the latter enzyme plays a key role for the electron flow through the formation of acetyl-CoA and its subsequent conversion to acetate, ethanol, butyrate, butanol, acetone, etc. Furthermore, the electron flow from glycolysis is balanced by the production of hydrogen gas, ethanol, butyrate and/or butanol. The ratio of the metabolites depends on the fermentation conditions; an extreme example is the biphasic fermentation of $C$. acetobutylicum. During the initial growth phase (the acidogenic phase) the organisms produce acetic and butyric acids, carbon dioxide and hydrogen gas, resulting in a pH decrease, while during the second phase (solventogenic phase; when the cultures enter the stationary growth phase) they produce acetone, butanol and almost no hydrogen gas, while the volatile fatty acids are partly reassimilated, resulting in an increase in $\mathrm{pH}$. There is a direct correlation between the levels of catabolic enzymes and the fermentation products formed (Andersch et al., 1983). Also the properties of LDH of this Clostridium reflect the conditions under which lactate is produced by the cells (Freier \& Gottschalk, 1987).

One of the aims of this study was to search for a possible correlation between LDH and ADH enzyme activities and the production of the respective metabolites, lactate and ethanol, during the $C$. thermosaccharolyticum fermentation. We have shown that when a continuous culture of $C$. thermosaccharolyticum LMG 6564 is run under glucose limitation, the ratio of the metabolites ethanol, lactate, hydrogen gas and carbon dioxide depends on the growth conditions (Vancanneyt et al., 1990). With glucose as fermentable sugar in the $\mathrm{pH}$ range 7.0-5.0, lactate and ethanol are the main endproducts. No lactate is formed at $\mathrm{pH} 7 \cdot 0$, when ethanol production is maximal; the opposite is true at $\mathrm{pH} 5.0$. Furthermore, the ethanol:lactate ratio changes drastically with the dilution rate. Secondly, we wished to investigate the role of the co-factors NADH and NADPH in relation to ADH and LDH activity. It has been shown or suggested that both co-factors can be involved in catabolic reactions. Because the changes in ethanol and lactate production by $C$. thermosaccharolyticum were demonstrated with continuous cultures (Vancanneyt et al., 1990), this culture technique was used in the present study.

\section{Methods}

Organism and growth conditions. C. thermosaccharolyticum LMG 6564 was grown anaerobically at $55^{\circ} \mathrm{C}$. It was maintained on the solidified basal medium ( $30 \mathrm{~g}$ agar $1^{-1}$ ) of Zeikus et al. (1979), supplemented with $3 \mathrm{~g}$ yeast extract, $10 \mathrm{~g}$ tryptone and $5 \mathrm{~g}$ glucose $1^{-1}$. Continuous culture experiments were performed in a 2.51 fermenter (Biolafitte) with a working volume of 1.21 or in a 0.51 culture vessel of our own design (D. Raspoet, B. Pot, D. De Deyn, P. De Vos, K. Kersters \& J. De Ley, unpublished results) with a working volume of 0.31 . As liquid culture medium we used the basal medium of Zeikus et al. (1979) without $\mathrm{Na}_{2} \mathrm{~S}$, but with the same amount of yeast extract and tryptone as above. The medium without the carbon source was autoclaved for $20 \mathrm{~min}$ (reactor) or $40 \mathrm{~min}\left(201 \mathrm{medium}\right.$ reservoir) at $120^{\circ} \mathrm{C}$. Glucose $(20 \%, w / v)$ and a silicone antifoam agent (Fluka AG; final concentration $250 \mu \mathrm{I}^{-1}$ ) were autoclaved separately at $120^{\circ} \mathrm{C}$ for $20 \mathrm{~min}$. A freshly prepared sodium thioglycolate solution (final concentration $0.5 \mathrm{~g} \mathrm{l}^{-1}$ ) was filter-sterilized and added aseptically before starting. The Biolafitte fermenter was stirred mechanically, the reactor of our own design magnetically. Both fermenters were run under $\mathrm{pH}$ control with $4 \mathrm{M}-\mathrm{NaOH}$. Anaerobic conditions were achieved by sparging the fermenter with $\mathrm{N}_{2}\left(220 \mathrm{ml} \mathrm{min}^{-1}\right)$ through a membrane air filter (pore size 0.2 $\mu \mathrm{m}$; Gelman Acro 50) for $30 \mathrm{~min}$. The medium in the reservoir was flushed continuously with sterile $\mathbf{N}_{2}$ at fivefold lower rate. A fixed culture level in the fermenters was achieved by an equilibrated in- and out-flow system with peristaltic pumps (Watson Marlow $501 \mathrm{U}$ ). The culture was checked daily for contamination by microscopic examination and by plating on nutrient agar (aerobic incubation at $55^{\circ} \mathrm{C}$ ) and on the medium of Zeikus et al. (1979) (anaerobic incubation).

Determination of glucose, fermentation products and cell dry weight. Glucose in reservoir media and culture supernatants was determined spectrophotometrically by the dinitrosalicylic acid method (Miller, 1959). The gas produced was captured under an inverted cylinder in water. Gas analyses were performed by gas chromatography as described previously (De Vos et al., 1983). Lactate was determined by gas chromatography as described by Holdeman et al. (1977). Ethanol, butanol, and acetic and butyric acids were also quantified by gas chromatography (GC Intersmat 121; FID) as described previously (Vancanneyt et al., 1987) with isobutyric acid $(0.018 \mathrm{M})$ as internal standard. For the determination of cell dry weight, $5 \mathrm{ml}$ of a grown culture was passed through a cellulose nitrate membrane filter (pore size $0.45 \mu \mathrm{m}$, diameter $47 \mathrm{~mm}$ ), which was dried overnight under vacuum and weighed.

Preparation of cell extracts and enzyme assays. Cells were harvested by centrifugation of 0.51 (Biolafitte fermenter) or 0.31 (fermenter of our own design) culture fluid at $12000 \mathrm{~g}$ for $10 \mathrm{~min}$ at $4{ }^{\circ} \mathrm{C}$ and washed once with $25 \mathrm{~mm}$-Tris/ $\mathrm{HCl}(\mathrm{pH} \mathrm{7.4)}$ plus $2 \mathrm{~mm}$-dithiothreitol buffer (Turunen et al., 1987). After another centrifugation, the cells were suspended in buffer as above ( $3 \mathrm{ml}$ per $\mathrm{g}$ wet weight) and passed through a French pressure cell $\left(1.5 \times 10^{8} \mathrm{~Pa}\right)$. After centrifugation at $12000 \mathrm{~g}$ for $10 \mathrm{~min}$ at $4{ }^{\circ} \mathrm{C}$, part of the supernatant (= crude cell extract) was stored at $-20^{\circ} \mathrm{C}$; the rest was cleared of cell debris by ultracentrifugation at $85000 \mathrm{~g}$ for $4 \mathrm{~h}$ at $4^{\circ} \mathrm{C}$; the supernatant (= cytoplasmic extract) was also stored at $-20^{\circ} \mathrm{C}$ (Kersters \& De Ley, 1975). All manipulations were performed either aerobically or anaerobically (under argon atmosphere) and standard enzyme assays were done at $50^{\circ} \mathrm{C}$.

The assays for $\mathrm{LDH}$ (cytoplasmic extract) contained, per ml, unless stated otherwise : $0.1 \mathrm{M}$-imidazole $/ \mathrm{HCl}(\mathrm{pH} \mathrm{6.4)}, 0.375 \mathrm{mM}-\mathrm{NAD}(\mathrm{P}) \mathrm{H}$, 2.5 mM-sodium pyruvate and $1 \mathrm{mM}-F B P$. The assays for ADH (crude cell extract) contained, per $\mathrm{ml}$, unless stated otherwise : $0 \cdot 1 \mathrm{M}-\mathrm{Tris} / \mathrm{HCl}$ (pH 7.8), 2 mM-dithiothreitol, $0.375 \mathrm{mM}-\mathrm{NAD}(\mathrm{P}) \mathrm{H}$ and $15 \mathrm{mM}$ acetaldehyde. The reaction was started by adding $25 \mu \mathrm{l}$ cell extract to 
the mixture. Protein was estimated by the Lowry method with bovine serum albumin as standard. The enzyme activity was expressed as the initial rate $\left[v ; \mathrm{min}^{-1}(\mathrm{mg} \text { protein })^{-1}\right]$ of substrate reduction calculated from $\Delta A \cdot d^{-1} \cdot \varepsilon^{-1}$, where $\Delta A$ is the change in absorbance at $340 \mathrm{~nm}$, a measure of the oxidation of $\mathrm{NAD}(\mathrm{P}) \mathrm{H} ; d$ is the light path; and $\varepsilon$ is the molar absorption coefficient of $\mathrm{NAD}(\mathrm{P}) \mathrm{H}$ at $340 \mathrm{~nm}$. The change in absorbance was followed during $2 \mathrm{~min}$. Measured enzyme activities were corrected for $\mathrm{NAD}(\mathrm{P}) \mathrm{H}$ oxidase activity.

Electrophoresis and gel staining. Discontinuous polyacrylamide gel electrophoresis on slab gels was done by a modification of the method of Davis (1964). We used an acrylamide/bisacrylamide mixture of $10 \%$ $(\mathrm{w} / \mathrm{v})(\mathrm{T}=40 \%$ and $\mathrm{C}=5 \% ; \mathrm{T}$ is the total percentage concentration of both monomers in the buffer, and $\mathrm{C}$ is the percentage concentration of $N, N^{\prime}$-methylene bisacrylamide relative to $\mathrm{T}$ ) in $1.00 \mathrm{M}$-Tris $/ \mathrm{HCl}$ (pH 8.88) for the separating gel and $5 \%(\mathrm{w} / \mathrm{v})$ in $150 \mathrm{~mm}$-Tris/phosphoric acid ( $\mathrm{pH} \mathrm{7.40)}$ ) for the stacking gel. LDH activity was located by the method described by Garvie (1969), modified as follows: for the direct staining, we used the method described by Turunen et al. (1987) and modified methods with different buffers (see below); for the indirect method, the gel was placed in a solution containing $1 \mathrm{mM}-\mathrm{FBP}$, $10 \mathrm{~mm}$-pyruvate and $1.4 \mathrm{~mm}$-NADH in $0.1 \mathrm{M}$-imidazole $/ \mathrm{HCl}(\mathrm{pH} \mathrm{6.2)}$ for $15 \mathrm{~min}$ at $55^{\circ} \mathrm{C}$. The gel was removed from the reaction mixture and stained in a solution containing, per $100 \mathrm{ml}, 0.1 \mathrm{M}$-Tris/maleate buffer (pH 8.3), $50 \mathrm{mg}$ nitroblue tetrazolium and $2.74 \mathrm{mg}$ phenazine methosulphate.

\section{Results and Discussion}

Lowering the $\mathrm{pH}$ and the dilution rate in a 0.51 reactor favours lactate formation (Vancanneyt et al., 1987, 1990). Table 1 shows data from analogous experiments with a larger culture vessel ( 1.21 culture volume: Biolafitte fermenter). The effect of $\mathrm{pH}$ and dilution rate was slightly different from the previous results (Vancanneyt et al., 1990). Again the highest ethanol production was found at the upper limit of the culture $\mathrm{pH}(7 \cdot 0)$. However, with $D=0.08-0 \cdot 10 \mathrm{~h}^{-1}$, the amount of lactate produced per mol glucose remained almost constant within the $\mathrm{pH}$ range 5.4-7.0. When the dilution rate was lowered to $0.03 \mathrm{~h}^{-1}$ at $\mathrm{pH} \mathrm{7.0}$, the lactate production decreased to $0.08 \mathrm{~mol}$ per mol glucose. When we used the smaller fermenter, no lactate was formed at $\mathrm{pH} \mathrm{7.0} \mathrm{and}$ $D=0.09 \mathrm{~h}^{-1}$ (Table 2). This different result with the two reactors was confirmed by triplicate experiments. A different stirring mechanism and/or a different design can affect certain parameters such as the dissolved $\mathbf{H}_{2}$ concentration in the culture fluid. This and/or the fact that one of the reactors contained an iron stirring axis probably explains the difference in fermentation pattern.

In vitro measurements of enzyme activities of aerobically and anaerobically prepared extracts from the fermentations are reported in Tables 1 and 2, respectively.

\section{Enzymes involved in lactate and ethanol production}

Tables 1 and 2 show that NADH-linked LDH activity was more than 20 times higher than the NADPH-linked activity in lactate-producing cells. Crude cell extracts and cytoplasmic cell extracts both had the same rate of pyruvate reduction (data not shown), indicating that this enzyme system is not found in the particulate fraction of the cell lysate. Garvie (1980) also reported that all NADH-linked LDHs from the lactic acid bacteria are cytoplasmic. We could not demonstrate lactate oxidation in C. thermosaccharolyticum extracts, either spectrophotometrically or on polyacrylamide gels (direct staining). We tested different buffer systems ( $0 \cdot 1 \mathrm{M}$-Tris/maleate, pH 8.3; $0.1 \mathrm{M}$-Tris/HCl, pH 7.0; 0.05 M-sodium carbonate, $\mathrm{pH}$ 9.2), different concentrations of DL-, $\mathrm{L}(+)$ - and $\mathrm{D}(-)$-lactate, and addition of $25 \mathrm{mM}-\mathrm{MgCl}_{2}$ and/or $1 \mathrm{mM}-\mathrm{FBP}$. We also tested a coupled reaction system with glutamate to trap the pyruvate formed in the first reaction (see below):

$$
\begin{array}{r}
\text { Lactate }+\mathrm{NAD}^{+} \longrightarrow \text { Pyruvate }+\mathrm{NADH}+\mathrm{H}^{+}(1) \\
\text { Glutamate }+ \text { Pyruvate } \stackrel{\text { GPT }}{\longrightarrow} \text { 2-Oxoglutarate + Alanine }
\end{array}
$$

(GPT, glutamate: pyruvate aminotransferase). It was the purpose of this coupled system to keep the pyruvate concentration lower so that the first reaction (1) is shifted to lactate oxidation. Turunen et al. (1987) showed the oxidation of L-lactate in C. thermohydrosulfuricum on polyacrylamide gel but not spectrophotometrically. On the other hand, Lamed \& Zeikus $(1980 b)$ could not demonstrate lactate oxidation with FBP-activated LLDH of $C$. thermocellum and $T$. brockii, which was also true for $\mathrm{L}(+)-\mathrm{LDH}$ of $C$. acetobutylicum (Freier \& Gottschalk, 1987).

With aerobically prepared cell extracts, weak NADHand NADPH-linked ADH activities were observed. The NADH-linked reaction is more sensitive to oxygen than the NADPH-linked reaction (data not shown), which was also true for ADH of $T$. brockii (Lamed \& Zeikus, $1980 a$ ). Furthermore, the reaction rate did not change after sparging the reaction mixture with argon for $15 \mathrm{~min}$ (data not shown). This means that oxygen affects the ADH activity irreversibly.

We found active ADH in the particulate fraction of the cell lysate only. This may be due to an association of these enzymes with membrane structures or, as was demonstrated for C. kluyveri (Lurz et al., 1979) in solution with an ionic strength above $25 \mathrm{~mm}$, to a precipitation of the dehydrogenase (complexes) in the form of polygonal bodies. The oxidation of ethanol with $\mathrm{NAD}^{+}$as electron acceptor could not be demonstrated; the NADP+mediated reaction was not tested.

The ratio of the activities of the NADH-mediated versus NADPH-mediated ADH reactions was approximately $3: 1$ at $\mathrm{pH} 7.0(1.10 \mathrm{~mol}$ ethanol per mol glucose) and $2: 3$ at $\mathrm{pH} 6.0(0.20 \mathrm{~mol}$ ethanol per mol glucose $)$ 
Table 1. Fermentation data for C. thermosaccharolyticum LMG 6564 in continuous cultures (Biolafitte fermenter) under glucose limitation (50 mM-glucose input) at various dilution rates and $\mathrm{pH}$ values

Data represent means of three samples for each steady state. Standard deviations were within 3-5\% of the mean. All steady states were repeated at least twice with the same results for the fermentation products formed (data not shown). The preparation of the cell extracts and the enzyme assays were performed aerobically.

\begin{tabular}{|c|c|c|c|c|c|c|c|c|c|c|c|}
\hline \multirow[b]{2}{*}{$\underset{\left(h^{-1}\right)}{D}$} & \multirow[b]{2}{*}{ pH } & \multirow[b]{2}{*}{$\begin{array}{c}\text { Glucose } \\
\text { consumed* }\end{array}$} & \multirow[b]{2}{*}{ Ethanol ${ }^{*}$} & \multirow[b]{2}{*}{ Acetate* } & \multirow[b]{2}{*}{ Butyrate* } & \multirow[b]{2}{*}{ Butanol $^{*}$} & \multirow[b]{2}{*}{ Lactate* } & \multirow[b]{2}{*}{$\underset{\text { gas } \dagger}{\mathbf{H}_{2}}$} & \multirow[b]{2}{*}{$\begin{array}{l}\text { Cell dry } \\
\text { weight }\end{array}$} & \multicolumn{2}{|c|}{$v$ of $\mathrm{LDH} \S$} \\
\hline & & & & & & & & & & $\begin{array}{l}\text { NADH- } \\
\text { linked }\end{array}$ & $\begin{array}{l}\text { NADPH- } \\
\text { linked }\end{array}$ \\
\hline $0 \cdot 10$ & $5 \cdot 4$ & 50 & $13(0.26)$ & $17(0.34)$ & $17(0.34)$ & $7(0 \cdot 14)$ & $15(0-30)$ & 1.72 & 1.56 & 1.32 & 0.035 \\
\hline 0.10 & 6.0 & 50 & $24(0.48)$ & $16(0.32)$ & $8(0.16)$ & $8(0 \cdot 16)$ & $20(0.40)$ & 1.36 & $1 \cdot 11$ & 1.53 & 0.064 \\
\hline 0.08 & 6.8 & 50 & $36(0.72)$ & $14(0.28)$ & $1(0.02)$ & $4(0.08)$ & $19(0.38)$ & 1.04 & 1.77 & 1.79 & 0.075 \\
\hline 0.08 & 7.0 & 50 & $47(0.94)$ & $20(0.40)$ & $2(0.04)$ & $6(0.12)$ & $20(0.40)$ & 1.04 & 1.05 & $2 \cdot 20$ & 0.077 \\
\hline 0.05 & 7.0 & 50 & $49(0.98)$ & $19(0.38)$ & $0(0.00)$ & $5(0.10)$ & $15(0.30)$ & 1.00 & 0.81 & $1 \cdot 34$ & 0.067 \\
\hline 0.03 & $7 \cdot 0$ & 50 & $52(1.04)$ & $28(0.56)$ & $2(0.04)$ & $6(0 \cdot 12)$ & $4(0.08)$ & 1.22 & 0.81 & 0.56 & 0.037 \\
\hline
\end{tabular}

* Expressed as $\mathrm{mm}$ and - in parentheses - as mol produced per mol glucose consumed.

$\dagger$ Expressed as mol produced per mol glucose consumed.

$\ddagger$ Expressed as $\mathrm{mg} \mathrm{m}^{-1}$.

$\S$ Expressed as $\mu \mathrm{mol}$ substrate reduced (mg protein) $)^{-1} \mathrm{~min}^{-1}$.

Table 2. Fermentation data for C. thermosaccharolyticum LMG 6564 in continuous cultures (0.3 l reactor) under glucose limitation (50 mM-glucose input) at $\mathrm{D}=0.09 \mathrm{~h}^{-1}$ and two different $\mathrm{pH}$ values

Data represent means from three samples for each steady state. Standard deviations were within 3-5\% of the mean. All steady states were repeated at least twice with the same results for the fermentation products formed (data not shown). The preparation of the cell extracts and the enzyme assays were performed anaerobically.

\begin{tabular}{|c|c|c|c|c|c|c|c|c|c|c|c|c|}
\hline \multirow[b]{2}{*}{ pH } & \multirow[b]{2}{*}{$\begin{array}{l}\text { Glucose } \\
\text { consumed }\end{array}$} & \multirow[b]{2}{*}{ Ethanol* } & \multirow[b]{2}{*}{ Acetate* } & \multirow[b]{2}{*}{ Butyrate* } & \multirow[b]{2}{*}{ Butanol* } & \multirow[b]{2}{*}{ Lactate* } & \multirow[b]{2}{*}{$\underset{\text { gas } \dagger}{\mathbf{H}_{2}}$} & \multirow[b]{2}{*}{$\begin{array}{l}\text { Cell dry } \\
\text { weight } \ddagger\end{array}$} & \multicolumn{2}{|c|}{$v$ of LDH§ } & \multicolumn{2}{|c|}{$v$ of $\mathrm{ADH} \S$} \\
\hline & & & & & & & & & $\begin{array}{l}\text { NADH- } \\
\text { linked }\end{array}$ & $\begin{array}{l}\text { NADPH- } \\
\text { linked }\end{array}$ & $\begin{array}{l}\text { NADH- } \\
\text { linked }\end{array}$ & $\begin{array}{l}\text { NADPH- } \\
\text { linked }\end{array}$ \\
\hline $\begin{array}{l}6.0 \\
7.0\end{array}$ & $\begin{array}{l}50 \\
50\end{array}$ & $\begin{array}{l}10(0-20) \\
55(1 \cdot 10)\end{array}$ & $\begin{array}{l}22(0.44) \\
23(0.46)\end{array}$ & $\begin{array}{r}16(0.32) \\
0(0.00)\end{array}$ & $\begin{array}{r}12(0.24) \\
4(0.08)\end{array}$ & $\begin{array}{r}24(0.48) \\
0(0.00)\end{array}$ & $\begin{array}{l}1.56 \\
0.74\end{array}$ & $\begin{array}{l}1 \cdot 14 \\
0.96\end{array}$ & $\begin{array}{l}2 \cdot 27 \\
0 \cdot 01\end{array}$ & $\begin{array}{l}0.056 \\
0.024\end{array}$ & $\begin{array}{l}0.079 \\
0.36\end{array}$ & $\begin{array}{l}0.12 \\
0.13\end{array}$ \\
\hline
\end{tabular}

* Expressed as $\mathrm{mm}$ in the culture and - in parentheses - as mol produced per mol glucose consumed.

$\dagger$ Expressed as mol produced per mol glucose consumed.

$\ddagger$ Expressed as $\mathrm{mg} \mathrm{ml}^{-1}$. 8.8).

$\S$ Expressed as $\mu \mathrm{mol}$ substrate reduced (mg protein) ${ }^{-1} \min ^{-1}$ (the $\mathrm{pH}$ for measuring NADH-linked ADH was 7.2 and for NADPH-linked ADH

(Table 2). This supports our view that the major part of the ethanol production is connected with the NADHmediated reaction rather than with an NADPHmediated activity. The NADPH-mediated ADH reaction in C. thermosaccharolyticum probably has only a limited catabolic function. This is not supported by the observation of Hsu \& Ordal (1970) that NADPH-linked $\mathrm{ADH}$ is responsible for ethanol production in sporulating cells of $C$. thermosaccharolyticum. However, the role of the NADH-mediated reaction could have been overlooked because the cell extracts were manipulated in the presence of oxygen. Turunen et al. (1987) reported that the NADPH-linked ADH activity in C. thermohydrosulfuricum was tenfold higher than the NADHlinked activity. However, it is not clear whether all manipulations for the preparation of the cell extracts were performed under anaerobic conditions.

The knowledge of ADH activities in thermophilic isolates is still very confusing. The present data suggest that strictly anaerobic conditions must be maintained throughout the whole preparation and measuring procedure to obtain reliable information on the function of this enzyme.

\section{General catalytic properties of $L D H$ and $A D H$ of C. thermosaccharolyticum}

The $\mathrm{pH}$ optima are shown in Fig. 1. The pyruvate reduction reaction (both NADH- and NADPH-linked) showed optimum activity between $\mathrm{pH} 6.0$ and 6.5 , which 


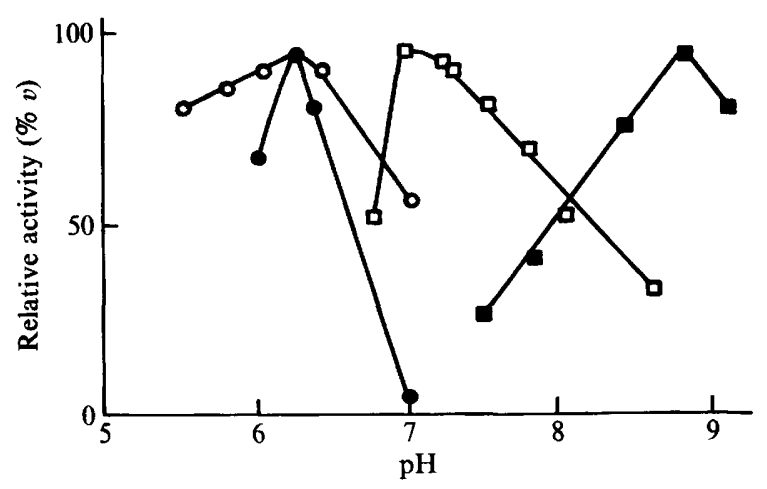

Fig. 1. Effect of $\mathrm{pH}$ on the activities (expressed as $\% v$ : the percentage of the maximum activity of the particular experiment) of the catabolic enzymes tested. Cytoplasmic and crude cell extracts from continuous cultures (Table 2) at pH 6.0 and 7.0 were used for LDH and ADH measurements, respectively. O, NADH-linked LDH; 9 , NADPHlinked LDH; $\square$, NADH-linked ADH; $\square$, NADPH-linked ADH.

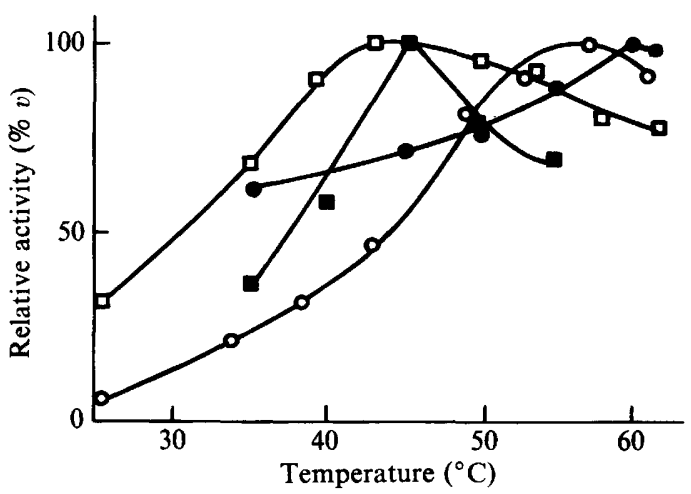

Fig. 2. Effect of temperature on the activities (expressed as $\% v$ : the percentage of the maximum activity of the particular experiment) of the catabolic enzymes tested. Cytoplasmic and crude cell extracts from continuous cultures (Table 2) at pH 6.0 and 7.0 were used for LDH and ADH measurements, respectively. $O$, NADH-linked LDH; $\bullet$, NADPH-linked LDH; $\square$, NADH-linked ADH; $\square$, NADPH-linked ADH.

is somewhat higher than the $\mathrm{pH} 5 \cdot 5-6 \cdot 0$ optimum for LDH from $C$. thermohydrosulfuricum (Turunen et al., 1987). In the case of acetaldehyde reduction two $\mathrm{pH}$ optima were apparent: 7.0 for NADH- and 8.8 for NADPH-linked ADH. This supports our conclusion about the presence of two different enzymes for ethanol formation. The $\mathrm{pH}$ optimum for NADPH-linked ADH of $T$. brockii is 7.8 (Lamed \& Zeikus, 1981). The pH optimum for the NADH-linked ADH of C. thermosaccharolyticum reflects the conditions for the highest ethanol production levels.
The effect of the incubation temperature on these enzyme activities is shown in Fig. 2. For NADH- and NADPH-linked LDH the in vitro optimum temperature under standard assay conditions was $55-60^{\circ} \mathrm{C}$, which is close to the optimal growth temperature (Vancanneyt $e t$ al., 1987). For ADH activity the temperature effect was clearly different. In the first place, the optimum temperature $\left(40-45^{\circ} \mathrm{C}\right)$ was lower than for LDH. This corresponds well with previous observations(Vancanneyt et al., 1987) that the ethanol yield with this strain is higher at $45-50{ }^{\circ} \mathrm{C}$ (definitely below the optimum growth temperature). Secondly, the temperature curves of NADH- and NADPH-mediated ADH were different. The former showed a rather broad optimum and the latter a sharp one. Again, this indicates that we are dealing with different enzymes, perhaps having different metabolic functions.

The effect of the substrate concentration on the activity of LDH (pyruvate) and ADH (acetaldehyde) was determined. In the case of ADH we determined $K_{\mathrm{m}}$ values of 2.3 and $2.0 \mathrm{mM}$ for the NADH- and NADPHlinked reaction, respectively. For $\mathrm{LDH}, K_{\mathrm{m}}$ values of 0.5 and $1.8 \mathrm{~mm}$ for the NADH- and NADPH-linked reaction, respectively, were found.

All LDH measurements were performed in the presence of $1 \mathrm{mM}$-FBP. In the assay conditions, (allosteric) stimulation of $C$. thermosaccharolyticum LDH by FBP is maximal with $1 \mathrm{mM}-\mathrm{FBP}$. However, the required FBP level may be affected by the type of buffer used, its concentration, the $\mathrm{pH}$, the pyruvate concentration and the bacterial strain (Garvie, 1980). Lamed \& Zeikus (1980a) mentioned that in the case of $T$. brockii LDH the affinity of the enzyme for the activator FBP was pH dependent, although the maximum activity of the reaction was constant in the $\mathrm{pH}$ range $6 \cdot 2-7 \cdot 8$. In general, FBP stimulation has been shown for LDHs of most streptococci, some lactobacilli (e.g. Lactobacillus casei) and several other mesophilic bacteria (Garvie, 1980). Freier \& Gottschalk (1987) demonstrated FBP stimulation for LDH of C. acetobutylicum, a mesophilic member of the saccharolytic clostridia. Furthermore, the activities of all LDHs from thermophilic bacteria thus far studied (Lamed \& Zeikus, 1980 a, $b$; Ben-Bassat $e t$ al., 1981 ; Clarke et al., 1986; Turunen et al., 1987) are FBP controlled. FBP activation leads to changes in the state of subunit associations (dimer or tetramer) at the time the affinity for pyruvate is increased and the tetrameric form of the enzyme is stabilized (Clarke et al., 1986).

\section{Correlation between LDH and/or ADH activity and metabolite formation in continuous culture}

Data on LDH and ADH activities (Tables 1 and 2) clearly show the direct correlations between lactate and 


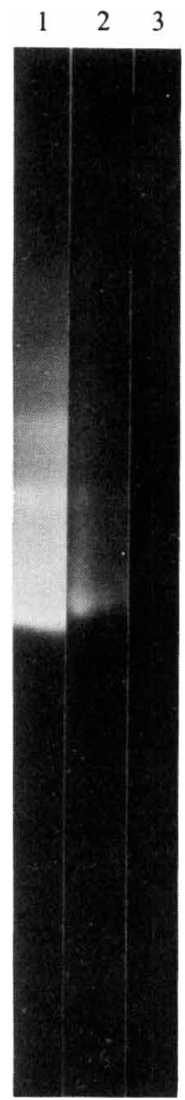

Fig. 3. LDH activities on slab gels; reverse staining; electrophoresis time $16 \mathrm{~h}$. Cell extracts ( $1.8 \mu \mathrm{g}$ protein) from a culture in the Biolafitte fermenter (Table 1) was loaded on lanes 1 and 2 and from a culture in the fermenter of our own design (Table 2) was loaded on lane 3 . Lane 1 , $D=0.08 \mathrm{~h}^{-1}, \mathrm{pH}=6.8$; lane $2, D=0.03 \mathrm{~h}^{-1}$, pH $=7.0 ;$ lane $3, D=0.09 \mathrm{~h}^{-1}, \mathrm{pH}=7.0$.

alcohol production in the fermenter and the in vitro measured activities of the NADH-linked LDH and ADH. LDH activity was also visualized on polyacrylamide gels (Fig. 3). A broad slow-moving FBPdependent LDH band in cell extract from $C$. thermosaccharolyticum was also observed in $C$. thermohydrosulfuricum extracts (Turunen et al., 1987). The activity (broadness of the band) on the gel and the spectrophotometric measurements of LDH activity matched well with the corresponding lactate production levels in the cultures. These data at least suggest a regulation of LDH at the level of synthesis in $C$. thermosaccharolyticum cultures. This is in contrast with, for example, LDH of Streptococcus mutans. Yamada \& Carlsson (1975) showed that intracellular LDH levels (measured as LDH activities of cell extracts) are of the same order of magnitude under homofermentative and heterofermentative conditions in continuous cultures of this organism. In L. casei (De Vries et al., 1970) the specific activity of LDH likewise did not change when the culture conditions were different. For $T$. brockii (Ben-Bassat et al., 1981) a lower lactate yield on starch than on glucose was correlated with a lower FBP level as a consequence of a slower metabolic activity.
Apparently, the LDH activity is controlled by the intracellular FBP concentration. Although we did not measure the intracellular concentration of this activator, the absolute requirement of LDH for FBP strongly suggests that the LDH activity in $C$. thermosaccharolyticum is also under a similar control (probably allosteric), as has been demonstrated for other FBP-dependent LDHs (Yamada \& Carlsson, 1975; Thomas et al., 1979; Ben-Bassat et al., 1981).

J.D.L. is indebted to the Belgian Ministry of Science Policy for the personnel and research grants OOA 80/85-7 and 85/90-76. M.V. is indebted to the IWONL (Instituut ter anmoediging van het Wetenschappelijk Onderzoek in Nijverheid en Landbouw) for a scholarship. P.D.V. is indebted to the National Fund for Scientific Research (Belgium) for a position as Research Associate.

\section{References}

ANDERSCH, W., BAHL, H. \& GotTschalK, G. (1983). Level of enzymes involved in acetate, butyrate, acetone and butanol formation by Clostridium acetobutylicum. European Journal of Applied Microbiology and Biotechnology 18, 327-332.

BeN-BASSAT, A., LAMED, R. \& ZeIKUS, J. G. (1981). Ethanol production by thermophilic bacteria: metabolic control of end product formation in Thermoanaerobium brockii. Journal of Bacteriology 146, 192-199.

Clark, S. W., BENNETT, G. N. \& RudolPH, F. B. (1989). Isolation and characterization of mutants of Clostridium acetobutylicum ATCC 824 deficient in acetoacetyl-coenzyme A: acetate/butyrate : coenzyme Atransferase (EC 2.8.3.9) and in other solvent pathway enzymes. Applied and Environmental Microbiology 55, 970-976.

Clarke, A. R., Evington, J. R. N., Dunn, C. R., Atkinson, T. \& HolBROOK, J. J. (1986). The molecular pathway by which fructose 1,6-bisphosphate induces the assembly of a bacterial lactate dehydrogenase. Biochimica et Biophysica Acta 870, 112-126.

DAvIs, B. J. (1964). Disc electrophoresis. II. Method and application to human serum proteins. Annals of the New York Academy of Sciences 121, 404-427.

De Vos, P., Stevens, P. \& De LeY, J. (1983). Hydrogen gas production from formate and glucose by different members of the Enterobacteriaceae. Biotechnology Letters 5, 69-74.

De Vries, W., Kapteyn, W. M. C., Van Der Beer, E. G. \& Stouthamer, A. H. (1970). Molar growth yields and fermentation balances of Lactobacillus case $\mathrm{L} 3$ in batch cultures and in continuous cultures. Journal of General Microbiology 63, 333-345.

Freier, D. \& GotTSCHALK, G. (1987). L(+)-Lactate dehydrogenase of Clostridium acetobutylicum is activated by fructose-1,6-bisphosphate. FEMS Microbiology Letters 43, 229-233.

GARVIE, E. I. (1969). Lactic dehydrogenases of strains of the genus Leuconostoc. Journal of General Microbiology 58, 85-94.

GARVIE, E. I. (1980). Bacterial lactate dehydrogenases. Microbiological Reviews 44, 106-139.

HiLlMeR, P. \& GotTschalK, G. (1972). Particulate nature of enzymes involved in the fermentation of ethanol and acetate by Clostridium kluyveri. FEBS Letters 21, 351-354.

Hillmer, P. \& GotTschalK, G. (1974). Solubilization and partial characterization of particulate dehydrogenase from Clostridium kluyveri. Biochimica et Biophysica Acta 334, 12-23.

Holdeman, L. V., Cato, E. P. \& Moore, W. E. C. (1977). Anaerobe Laboratory Manual, Blackburg, Virginia: Southern Printing Co.

HsU, E. J. \& ORDAL, Z. J. (1970). Comparative metabolism of vegetative and sporulating cultures of Clostridium thermosaccharolyticum. Journal of Bacteriology 102, 369-376. 
Hyun, H. H., Shen, G. J. \& Zeikus, J. G. (1985). Differential amylosaccharide metabolism of Clostridium thermosulfurogenes and Clostridium thermohydrosulfuricum. Journal of Bacteriology 164, 11531161.

JoNES, D. T. \& WooDs, D. R. (1986). Acetone-butanol fermentation revisited. Microbiological Reviews 50, 484-524.

Jungermann, K., Thauer, R. K., Leimenstoll, G. \& Decker, K. (1973). Function of reduced pyridine nucleotide-ferredoxin oxidoreductases in saccharolytic clostridia. Biochimica et Biophysica Acta 305, 268-280.

KeRSTERS, K. \& DE LEY, J. (1975). Identification and grouping of bacteria by numerical analysis of their electrophoretic protein pattern. Journal of General Microbiology 87, 333-342.

LAMED, R. \& ZEIKUS, J. G. (1980a). Glucose fermentation pathway of Thermoanaerobium brockii. Journal of Bacteriology 141, 1251-1257.

LAMED, R. \& ZeIKUS, J. G. $(1980 b)$. Ethanol production by thermophilic bacteria: relationship between fermentation product yields of and catabolic enzyme activities in Clostridium thermocellum and Thermoanaerobium brockii. Journal of Bacteriology 144, 569-578.

LAMED, R. \& Zeikus, J. G. (1981). Novel NADP-linked alcoholaldehyde/ketone oxidoreductase in thermophilic ethanologenic bacteria. Biochemical Journal 195, 183-190.

LURZ, R., MAYER, F. \& GOTTSCHALK, G. (1979). Electron microscopic study on the quaternary structure of the isolated particulate alcoholacetaldehyde dehydrogenase complex and on its identity with the polygonal bodies of Clostridium kluyveri. Archives of Microbiology 120, 255-262.

MILLER, G. L. (1959). Use of dinitrosalicylic reagent for the determination of reducing sugars. Analytical Chemistry 31, 426-428.

Mitchell, W. J., ROOHI, M. S., Mosely, M. J. \& BOOTH, I. R. (1987) Regulation of carbohydrate utilization in Clostridium pasteurianum. Journal of General Microbiology 133, 31-36.

Petitdemange, H., Cherrier, C., Raval, G. \& Gay, R. (1976). Regulation of the NADH and NADPH-ferredoxin oxidoreductases in clostridia of the butyric group. Biochimica et Biophysica Acta 421 , 334-347.
Rao, G. \& Mutharasan, R. (1989). NADH levels and solventogenesis in Clostridium acetobutylicum: new insights through culture fluorescence. Applied Microbiology and Biotechnology 30, 59-60.

Thomas, T. D., Ellwood, D. C. \& LongYear, V. M. (1979). Change from homo- to heterolactic fermentation by Streptococcus lactis resulting from glucose limitation in anaerobic chemostat cultures. Journal of Bacteriology 138, 109-117.

Turunen, M., Parkkinen, E., Londesborough, J. \& Korhola, M. (1987). Distinct forms of lactate dehydrogenase purified from ethanol- and lactate-producing cells of Clostridium thermohydrosulfuricum. Journal of General Microbiology 133, 2865-2873.

VANCANNEYT, M., DE VOS, P. \& DE LEY, J. (1987). Ethanol production from glucose by Clostridium thermosaccharolyticum strains: effect of pH and temperature. Biotechnology Letters 9, 567-572.

Vancanneyt, M., De Vos, P., Marras, M. \& De Ley, J. (1990) Ethanol production in batch and continuous culture from some carbohydrates with Clostridium thermosaccharolyticum LMG 6564. Systematic and Applied Microbiology (in the Press).

Wiesengorn, D. P., Rudolph, F. B. \& Papoutsakis, E. T. (1989a). Phosphotransbutyrylase from Clostridium acetobutylicum ATCC 824 and its role in acidogenesis. Applied and Environmental Microbiology $55,317-322$.

Wiesenborn, D. P., Rudolph, F. B. \& Papoutsakis, E. T. $(1989 b)$ Coenzyme A transferase from Clostridium acetobutylicum ATCC 824 and its role in the uptake of acids. Applied and Environmental Microbiology 55, 323-329.

WoLIN, M. J. (1964). Fructose, 1,6-diphosphate requirement of streptococcal lactic dehydrogenase. Science 146, 775-776.

YAMADA, T. \& CARLSSON, J. (1975). Regulation of lactate dehydrogenase and change of fermentation products in streptococci. Journal of Bacteriology 124, 55-61.

ZeIKUS, J. G. (1979). Thermophilic bacteria: ecology, physiology and technology. Enzyme and Microbial Technology 1, 243-252.

Zeikus, J. G., Hegge, P. W. \& ANderson, M. A. (1979). Thermoanaerobium brockii gen. nov. and sp. nov., a new chemoorganotrophic caldoactive, anaerobic bacterium. Archives of Microbiology 122, 41-48. 